\title{
Evaluation of Learning Implementation using CIPP Model in SMK
}

\author{
$1^{\text {st }}$ Amidatus Sholihat Jamil \\ Vocational Education, State University of Malang \\ Malang, Indonesia \\ sparklingamidah@gmail.com
}

\author{
$2^{\text {nd }}$ Amat Mukhadis \\ State University of Malang \\ Malang, Indonesia
}

\begin{abstract}
This study aims to evaluate the implementation of productive learning of multimedia competence in $\mathrm{SMK}$, in terms of context, input, process, and product. This research was conducted at SMKN 1 Grati, Pasuruan. The research design used is qualitative research with the subject of research done by purposive sampling technique and set principal, vice principal of sarpras field and curriculum, head of skill competence, multimedia productive teacher, and student of class XI competence of multimedia expert as a research subject. using questionnaires, observations and interviews. Conducted instrument prerequisite test for questionnaire and grain validity for interview and observation guidelines. Data analysis technique used qualitative descriptive analysis with multisitus analysis. The results show that there are standards that must be equalized, ranging from the policy of the establishment of competence skills that affect bias on the learning process until the output. (Abstract)
\end{abstract}

Keywords- evaluation, CIPP model, productive learning, multimedia

\section{INTRODUCTION}

Efforts to improve the learning process, of course, is done by all the people who are in the educational environment, including teachers, students, parents, principals to educational personnel. To make improvements in the learning process must be evaluated on the learning process that has been going before. So as to evaluate the learning process of in-depth planning concerning the purpose of evaluation to the final outcome to be evaluated [6].

Competence Multimedia Expertise is one of the existing programs in the group of productive subjects in SMK. Competence of Multimedia Expertise is one of Skills Competence which is quite popular in Pasuruan Regency. Pasuruan Regency is a developing district in East Java Province that always improves the equity of learning opportunities and improves the quality of education at all levels.

SMK has been established in many cities and districts, especially in East Java. SMKN 1 Grati is a long established school in Pasuruan, precisely located on the highway ngopak. Pasuruan regency is one of the regencies located in East Java. Competence of Multimedia expertise is a new competency of kemalian which was first opened in 2011 at SMKN 1 Grati. How is the implementation of multimedia productive learning in SMK Negeri in Pasuruan Regency evaluated with CIPP model ?.

So far, there has been no evaluation of productive learning at SMK Negeri in Pasuruan especially in the competence of multimedia expertise. With the evaluation, it is expected to know the extent to which the implementation of multimedia productive learning in SMKN 1 Grati which for more or less step in the third year of this walk. The evaluation model used is CIPP Model, Context, Input, Procces, Product. The CIPP model is similar to Stake's and CSE-UCLA models where all three tend to be comprehensive and start of the evaluation process during the planning stages of program development (Kaufman and Thomas, 1980).

implementation of learning. Things that need to be evaluated in terms of implementation of learning consists of four dimensions according to the CIPP model, namely context (context), input (input), process (process), outcome (product). For the context dimension is focused on the policy of provision of competence of keahllian, the socioeconomic condition of the students and the capacity of society to the competence of multimedia expertise in SMK, for input dimension focused on the input of human resources (teacher, student) and other resources (fund, equipment, materials) competence of multimedia expertise in SMK, while for the dimension of the process focused on the implementation of learning (including planning, implementation, and evaluation) on the implementation of learning productive subjects on the competence of multimedia expertise in SMK, for product dimension focused on the learning of multimedia productive subjects academic and problems and obstacles faced by students in the implementation of multimedia productive learning subjects in SMK. This is what makes this evaluation done so that the purpose of this evaluation is to reveal the implementation of learning subjects productive competence of multimedia in SMK.

\section{RESEARCH METHOD}

The research design used is qualitative research by using CIPP model oriented on program evaluation oriented approach to management which is a picture showing procedure and program execution process. This research includes evaluation of the background of the establishment of competence of multimedia expertise to productive learning result, this research is aimed to obtain the result of judgment and decision. The 
evaluation model used in this research is the CIPP evaluation model with the subjects of class XI multimedia research, multimedia productive teachers, principals, deputy head of curriculum, student, infrastructure and quality management at SMKN 1 Grati. This study was analyzed using qualitative analysis, with the implementation of the study still referring to the components being evaluated. The aspects of each component are described in Table 1.

TABLE I. COMPONENT OF LEARNING OF MULTIMEDIA

\begin{tabular}{|c|c|}
\hline Component & Indicator \\
\hline $\begin{array}{c}\text { Context } \\
\text { Component }\end{array}$ & $\begin{array}{l}\text { 1. Policy in the provision of Multimedia Expertise } \\
\text { Competence } \\
\text { 2. The geographical and socioeconomic conditions } \\
\text { of students Competency of Multimedia } \\
\text { Expertise } \\
\text { 3. Capacity of the community to the Competence } \\
\text { of Multimedia Expertise }\end{array}$ \\
\hline $\begin{array}{c}\text { Input } \\
\text { Component }\end{array}$ & $\begin{array}{l}\text { 1. Human resources (Teachers, Students) } \\
\text { Competency of Multimedia Expertise } \\
\text { 2. Other resources (funds, equipment, equipment, } \\
\text { materials) Competency of Multimedia Expertise }\end{array}$ \\
\hline $\begin{array}{c}\text { Process } \\
\text { Component }\end{array}$ & $\begin{array}{l}\text { 1. Planning the learning of multimedia } \\
\text { productive subjects is good } \\
\text { The implementation process of teaching and } \\
\text { learning effective multimedia productive } \\
\text { subjects } \\
\text { 3. Creation of a safe and orderly classroom } \\
\text { environment } \\
\text { 4. Evaluation and improvement of multimedia } \\
\text { productive subjects }\end{array}$ \\
\hline $\begin{array}{l}\text { Product } \\
\text { Component: } \\
\text { Output }\end{array}$ & $\begin{array}{l}\text { Learning outcomes of academic productive } \\
\text { subjects that are academic } \\
\text { 2. Problems and obstacles faced by students }\end{array}$ \\
\hline
\end{tabular}

Data collection techniques used include interviews, observation, and documentation studies. The data collected through the three techniques are analyzed, interpreted, and analyzed over and over again both through site-based analysis and cross-site analysis to find propositions for research findings. Data analysis begins by examining all data collected from various sources, ie from observations, interviews and documentation studies. The data collected will not give meaning if it is not analyzed. Data analysis for a component of context, input, and process is done by qualitative analysis technique inductively, that is by comparing data collected in the field with the provisions of the process of implementing productive learning that has been determined by the government.

\section{RESULT AND DISCUSSION}

The first component is defined as the contextComponent. From the exposure of data in SMK Negeri 1 Grati, found a number of research findings with the components of the context of policy indicators for the provision of competence of multimedia expertise, the geographical and socio-economic conditions of students competence of multimedia skills, and the capacity of the community to competence of multimedia, 1) Headmaster with deputy head of quality management conduct market needs analysis, (2) Deputy head of quality management conduct analysis on the existence of same skill competency in SMK around SMK Negeri 1 Grati, (3) geographical condition and socio-economic of student competence skill multimedia in SMK Negeri 1 Grati is not only viewed from small scope, but also broader scope to national scale, (4) Community support capacity to the competence of multimedia expertise in SMK Negeri 1 Grati, one of which is indicated by the many people who send their son and daughter in multimedia competence skill in SMK Negeri 1 Grati.

The second component is defined as the Input Component. From the exposure of the data in SMK Negeri 1 Grati, found a number of research findings with components Input indicators Human resources and other resources competence multimedia expertise, the findings are: (1) anyone can become multimedia productive teachers in SMK Negeri 1 Grati as long as have educational background that is considered linear and SMK Negeri 1 Grati still need, (2) prospective students of multimedia competence skills are required to have basic knowledge about the world of IT and prospective students should not be color blind, (3) Other resources are needed to support the process of productive learning multimedia in SMK Negeri 1 Grati, a fund sufficient to equip the infrastructure and infrastructure.

The third component is defined as a Process Component. From the exposure of the data in SMK Negeri 1 Grati, found a number of research findings with components The process of planning indicators, implementation, and evaluation of learning subjects productive competence of multimedia expertise, the findings are: (1) at the beginning of the school year, teachers make RPP as a form (2) The learning process implemented at SMK Negeri 1 Grati takes place not only in the classroom, workshop / laboratory, but also in the industry when the students carry out industrial work practices, (3) productive teachers determine the value KKM for multimedia productive subjects as benchmarks of students' learning mastery evaluation, if the results of evaluation is still below the value of $\mathrm{KKM}$ it will be remedial once, then the student is considered to pass and complete KKM.

The latter component is defined as Product Components. From the exposure of data that has been submitted, found a number of research findings on the output components of learning outcomes indicators and student learning barriers, the findings are: 1) there are significant differences in student learning barriers which include interest, socio-economic conditions, teacher interaction, facilities and infrastructure, and presentation of the material, 2) the learning outcomes shown in the student report cards appear to be above the KKM level of multimedia productive subjects but the grade average still stressed on the KKM score.

The fifth verse of the Director General of Management of Primary and Secondary Education Number: 251 / C / KEP / MN / 2008 states that the addition and / or changes in the competence of expertise are stipulated by the Head of the Education Office in accordance with their authority. Pasuruan Regency determined that the establishment of a new skills competency in an SMK ideally refers to the strategic plan (renstra) which is the elaboration of the plan long and middle of a city or district. The strategic plan of Pasuruan Regency regarding the establishment of a skill competency in SMK refers to several things, namely: (1) DUDI workforce needs, 
(2) Regional or local potential, (3) Increase in student participation rate, (4) Utilization of resources regions, and (5) utilization of human resources in a region.

Implementation of educational affairs as one of the regional authority becomes very important because it is one of the basic service functions of society. Educational issues are an important aspect from region to national. Preparation of RPJM Daerah also there is a vision of development to form a quality education. Before the RPJM Daerah is outlined in annual activities, the first thing to do is to develop a strategic plan that contains bureaucratic analysis to achieve the objectives contained in the RPJM. The activities of drafting the strategic plan by the local government work unit including the education office is actually a must to do (Paul, 2013).

By examining the comparison between substantive case groups, where substantive as a strategic liaison in focusing and formulating a formal theory based on the data, this study was reviewed based on the findings data about the background of the establishment of multimedia skills competence in SMK. Based on the facts of the research findings on the site in the context component and the background indicators of the establishment of a competency of expertise, that the principal must know what the strategic plan in each city / district, because of the strategy plan will be translated into what items which serve as the basis for the determination of the establishment of skill competency.

The importance of ideas in the planning of the establishment of skills competence should also involve the availability of facilities that will support the student learning process (Luneburg, 2011). According to [7], the development of SMK should take into account the characteristics of the local area. Where according to (Third, 2002), characteristics are special features; has a special characteristic in accordance with certain cautions that distinguish something from something else. Thus, regional characteristics are special features attached to the area, marking a region or potential that is seeded and distinguishable with other regions. It can be concluded that each city / district may have different criteria based on different possible strategic plans from each city / district and impact on the policy of establishing a new skill competency in SMK.

The establishment of new skills competencies, not necessarily is opened directly without any submission to the local education office. In the era of regional autonomy, the duties, functions, and roles of the Kabupaten / Kota Education Office are much larger than in the previous era. The District / City Education Office, formerly a central and provincial government education policy implementer, is now authorized to develop education policies for its districts [2].

Having taken into account the background of its establishment, then proceed with a SWOT analysis. Besides, the establishment of barau competence is based on the consideration that the focus refers to the market needs, both from the surrounding community, as well as the demands of the fulfillment of DUDI workers who bberhubungan with the competence of multimedia expertise. In addition to some of the things that respond to the needs of the market in establishing a competency of expertise, which needs to be considered is the existence of the same competence skills in other schools that exist in the school area itself.

Based on the facts of the research findings on the two sites in the context component, both of them analyzed the basic needs of the establishment of a competency of expertise, ranging from market needs, community, workforce in DUDI, to each item description of SWOT, ie strong, weakness, opportunity, and treath.

This is in line with what is contained in BSNP Year 2006 about the context analysis in the implementation of the preparation of KTSP in the form of self evaluation (self evaluation) of the school. This can be done by applying the SWOT approach (strengths, weaknesses, opportunities, and threats). In this case an internal environmental as sessment can be applied to understand strengths or strengths and weaknesses or weaknesses, as well as external environmental studies to uncover opportunities or opportunities and threats or challenges. So it can be concluded that SMKN 1 Grati in the case before forming or establishing a competency of expertise one of the requirements is to conduct a SWOT analysis and market demand analysis is in accordance with existing standards in BSNP dikarekanan establishment of competence expertise included in the context analysis on the implementation of SBC preparation.

In addition to referring to the strategic plan of Pasuruan district, before establishing a new skill competency in SMK ideally feasibility study of the region starting from the presence area of SMK then extends to the district. The geographical condition of the students in a skill competency is closely related to the existence of DUDI in the area around the school, because it becomes an influence on the socio-economic condition of the students on a competency of expertise.

It is known that human resources (HR) as a provider of education that has high competence and work professionally according to their fields is needed. Teachers are human resources who play an important role in the learning process in SMK. Because only from professional teachers and quality schools, quality human resources can be obtained [15].

The Law of National Education System Number 20 The year 2003 does not elaborate further on what professional teachers mean. Article 42 paragraph 1 states that a teachermust have minimum qualifications and certification in accordance with the level of teaching authority whose provisions are regulated by government regulations. In Government Regulation No. 19/2005 on National Education Standards (SNP), it is not clearly stated that the teacher is a position and / or professional job. Article 28, paragraph 3 only states that a teacher as a learning agent is required to have professional competence and other competencies such as pedagogic competence, pers onality competence, profes sional competence, and social competence. Furthermore, it is stated that every educator at every level of education must have minimum D4 or undergraduate academic qualifications in the field or educational program in accordance with the field taught or in accordance with the level of teaching place and must also have a profes sional teacher certificate (Article 29). 
This causes the absence of special standards owned by both schools in terms of recruitment of productive teachers as one of the keys to maintaining the quality of the implementation of productive learning competence of multimedia expertise in SMK. On the other hand according to [4]. Policy makers should also study the relationship between teachers and teacher acceptance standards before embarking on in-depth teaching.

Teachers become the front guard in the implementation of education in Indonesia. The success of education is in the hands of teachers. Teachers are individuals who deal directly with learners in the classroom in learning. Teachers have an important role to make learners of good quality academic, skill, emotional, moral and spiritual maturity. To support all that, required a teacher who has qualifications, competence, and high dedication in carrying out its duties [1].

According to (Guili, 2011) every teacher candidate should be selected also in terms of teaching experience in schools or other educational institutions, in order to demonstrate that teachers can mingle with prospective students who will be educated. Meanwhile, according to [11] every prospective productive teacher in SMK besides having diploma S1 and D4, the teacher must have certificate of competence and professional certificate issued by college which have program of procurement of educational staff and accredited minimum B as formal evidence of authority recognition for has minimum academic qualification and certificate of competence.

In addition to teachers, students are also one of the most important human resources in school management systems. In the world of education, students are a raw component, meaning students with all the characteristics initially are subjects that will be educated through various learning activities so that the output or graduates as expected [3].

Basically all the components of learning in schools must be maintained and always improved quality so that the results or output will also be good. Just like teachers, students' inputs must also be maintained in quality. In SMK Negeri 1 Grati there is no specific test for teacher acceptance, it's just that the requirements for prospective students should not be color blind and must have basic skills in the IT field.

Based on existing facts, it is deemed necessary to have a special test of interest as well as incorporated into the requirements submitted at the beginning of the registration. So that later, will be obtained a significant result in the value of each test students who will then be used as a reference for student acceptance in the competence of multimedia expertise.

Input education is said to be quality if the school input is done harmoniously one of the inputs of students, so as to create a qualified student candidate. The quality of the students input indicators are: (1) The NEM score of the students enrolling in the school is experiencing peninkatan, (2) When the admission of new students is never lack of students, (3) the test is done when the acceptance of prospective students according to their field [5].

Other resources are also needed in order to help implement a good productive learning process on the competence of multimedia expertise in each school, such as funding and infrastructure that support the productive learning process of multimedia expertise competence.

At the technical level, the system of distribution of funds from the education office can be classified into two types, namely: direct system and indirect system. Direct distribution in the context of school facilities and infrastructure means that the allocated budget is directly handed over to schools to be managed independently. While the indirect distribution means the management of the budget is done through a tender mechanism first. Furthermore, the winning bidders who manage the budget and the schoolstay receive the facilities and infrastructure.

Furthermore after the facilities and infrastructure have been received by the school, the distribution can be done directly or indirectly. Using a direct distribution system means that school facilities and infrastructure already received and inventoried are channeled directly to the unit or school personnel in need without going through the storage process. In contrast, the indirect distribution system means that school facilities and infrastructure that have been received and inventoried are not directly channeled, but must be stored in storage warehouse regularly [12].

In fact, in SMKN 1 Grati in terms of distribution of infrastructure facilities to support the process of productive multimedia learning using the submission system of competence expertise, then then given in accordance with the submission. This is if adjusted with the previous explanation then including the type of distribution is not direct because not as a whole directly given but through the process of filing.

The availability of adequate facilities and infrastructure will certainly be very helpful in the implementation of multimedia productive learning in both vocational schools. Zulfikar [16] argued that the facilities and infrastructure of the practice is anything that is directly related to the teaching and learning process such as room facilities, furniture, practical equipment (measuring instruments and hand tools), practice materials, learning media to achieve learning objectives.

From the above explanation can be concluded that when the facilities and infrastructure in practice are not fulfilled properly it will make it difficult for students to practice. Productive subjects in SMK, 70\% are practical, so if in the case of student practice is not fulfilled its needs, obviously will hinder the practice process. This is in accordance with the results of Rosivia's research in 2014 on the management of school infrastructure which suggests that Availability of ready-made infrastructure facilities when needed will also support the learning process of students, especially during practice. When the availability of prasana facilities is sufficient, it is followed by a good management process also to be used for a longer period of time, in addition to the management of facilities and infrastructure aims to create a condition conducive, comfortable and safe in the learning process [8].

The implementation of productive learning as contained in the lesson plan plan (RPP) is divided into three parts: preliminary activities, this activity or the formation of competence, and closing activities. All activities are recorded on the learning agenda consisting of the class agenda and 
teacher agenda. The classroom agenda is used to record all activities / learning materials in the classroom / laboratory / workshop, while the teacher's agenda is used to record all teacher activities in carrying out the lesson.

This is in accordance with the results of research Suryanto in 2012 about the implementation of productive practice learning in SMK which states that learning activities, es pecially for learning productive practice starting from the beginning of class X until the end of class XII. Productive subjects (vocational) is a core or a special feature for SMK, this is what distinguishes with other types of equivalent schools. Suryanto also stated that the process of productive learning in SMK includes three things namely the opening or preliminary activities, then the competence development activities, and continued with closing activities. The process of implementing productive learning in SMK bias implemented with various kinds of learning model according to Suryanto. Productive learning in SMK can be implemented by using competencybased, production-based, and industry-based learning model.

The process of assessment of productive learning is the assessment of the teacher directly, to determine the level of achievement and competence that has been determined by the learners. Sanjaya [9] states that as sessment is an integral part of the learning process which is carried out as a process of collecting and utilizing comprehensive information about learning outcomes obtained by students to determine the level of achievement and mastery of competencies as determined in the improvement of the learning process.

The results of the field research at SMKN 1 Grati show that the assessments made on productive subjects include (a) written, oral and practice assessments (project, product or performance), (b) assessment carried out at the end of the competency standard, (c) the criterion of the student is said to be competent or graduated if it meets the minimum score equal to 76, and (d) the form of the student's assessment in the form of daily test, midterm, semester end and class increase. This is in accordance with Permendiknas no. 20 Year 2007 on Education Assessment Standards which states the assessment of learning outcomes by educators can use using various as ses sment techniques in the form of test (written test, oral test, and practice test or performance test), observation, individual or group assignment, and other forms corresponding to characteristics of competence and level of development of learners. Besides, it was stated that the repetition form of daily test, mid semester test, semester final repetition, and repetition of class increase is done by educator under the coordination of educational unit.

The evaluation strategy is essentially an integral part of the productive program's learning, since the evaluation system has been formulated in the learning design. This is in accordance with the results of research by Setyohandani [10] on evaluation strategy on SMK productive learning which states that evaluation of learning outcomes is one part of the process of education and training, meaning that planning and implementation of the assessment must always refer to and in line with the principles of education and vocational training. Implementation of assessment / evaluation of learning result of the productive program can be applied in the stage: (1) formative evaluation; (2) evaluation of learning outcomes (summative evaluation); and (3) competence evaluation. Formative evaluation is a process of assessment by teachers as an integral part of the learning process (Setyohandani, 2013).

Product component in this research is the result obtained during teaching learning process progress, which includes affective, cognitive and psychomotor result which as a whole contained in report result report of the student. Of these three aspects, the Minimum Exhaustiveness Criteria (KKM) established by the school is 76. In accordance with the research objectives, the product components obtained during KBM play an important role, according to Bloom cited by Hamalik (2004: 87), the purpose of learning is divided into three aspects: (1) Cognitive Aspects (cognitive domains), including: recognition, knowledge, understanding, analysis, synthesis and evaluation, (2) Affective aspects, including: attitudes, emotions and moral characteristics is a psychological aspect of students, (3) Psychomotor aspect (psychomotor domain), is the mastery of skills supported by the integrity of limbs that will be involved in various types of activities. Psychomass aspects include: perception, readiness, mechanis $\mathrm{m}$, skill and adaptation.

Learning outcomes in SMK Negeri 1 Grati which can be said on average is on the minimum criteria of skill can be due to various things such as lack of infrastructure, or lack of educators who are linear.

Several studies related to the effect of infrastructure procurement on student learning process can be seen in research conducted by Tukiman [13] stated that the amount of practice equipment is very influential in the process of learning practice. A sufficient amount of practice equipment can ensure the implementation of the practice more freely, so that students have more experience. Likewise with the results of research Fauziati (2009) states that there is a positive relationship between the condition of facilities to the achievement of learning outcomes, a positive relationship indicates that if the means have a high value then the learning will be high too.

Several studies related to the influence of qualification of teacher competence on the learning process can be seen in research conducted by Winarto [14] stated that there are facts in the field showing teacher education qualifications in international schools in Malang is still not linear or in accordance with the science he learned before meaning that teachers who do not come from graduates of informatics engineering education or who are allied will have difficulty teaching in SMK multimedia majors, so it can be ascertained he can work professionally.

Along with the visible evidence on student learning outcomes on Implementation of multimedia productive learning lessons at two SMK in Pasuruan regency can not be separated from some obstacles or obstacles. To address the different constraints in each school, the school seeks to make effective use of existing resources and funds, so that if any shortcomings can be known.

\section{CONCLUSION}

The first component is defined as the context Component, 1) Headmaster with deputy head of quality management 
conduct market needs analysis, (2) Deputy head of quality management conduct analysis on the existence of same skill competency in SMK around SMK Negeri 1 Grati, (3) geographical condition and socio-economic of student competence skill multimedia in SMK Negeri 1 Grati is not only viewed from small scope, but also broader scope to national scale, (4) Community support capacity to the competence of multimedia expertise in SMK Negeri 1 Grati, one of which is indicated by the many people who send their son and daughter in multimedia competence skill in SMK Negeri 1 Grati.

The second component is defined as the Input Component, the findings are: (1) anyone can become multimedia productive teachers in SMK Negeri 1 Grati as long as have educational background that is considered linear and SMK Negeri 1 Grati still need, (2) prospective students of multimedia competence skills are required to have basic knowledge about the world of IT and prospective students should not be color blind, (3) Other resources are needed to support the process of productive learning multimedia in SMK Negeri 1 Grati, a fund sufficient to equip the infrastructure and infrastructure.

The third component is defined as a Process Component, the findings are: (1) at the beginning of the school year, teachers make RPP as a form (2) The learning process implemented at SMK Negeri 1 Grati takes place not only in the classroom, workshop / laboratory, but also in the industry when the students carry out industrial work practices, (3) productive teachers determine the value KKM for multimedia productive subjects as benchmarks of students' learning mastery evaluation, if the results of evaluation is still below the value of $\mathrm{KKM}$ it will be remedial once, then the student is considered to pass and complete KKM.

The latter component is defined as Product Components, the findings are: 1) there are significant differences in student learning barriers which include interest, socio-economic conditions, teacher interaction, facilities and infrastructure, and presentation of the material, 2) the learning outcomes shown in the student report cards appear to be above the KKM level of multimedia productive subjects but the grade average still stressed on the KKM score.

\section{REFERENCES}

[1] Alawiyah, F. 2013. Peran Guru dalam Kurikulum 2013. Jurnal Aspirasi, Volume 4, nomor 1: halaman 65-74.

[2] Andriani, Dwi Esti. 2008. Kajian Konseptual Restrukturisasi Dinas Pendidikan Kota/Kabupaten Di Era Otonomi Daerah. Jurnal Manajemen Pendidikan UNY. Volume 4, nomor 1: halaman 20-33.

[3] Bafadal, Ibrahim. 2003. Manajemen Peningkatan Mutu Sekolah Dasar. Jakarta: Bumi Aksara.

[4] Choi, P., \& Tang, S. 2011. Satisfied And Dissatisfied Commitment: Teachers In Three Generations. Australian Journal of Teacher Education, Volume 36, nomor 7: halaman 45-75.

[5] Hermawan, Dafit. 2013. Manajemen Kesiswaan untuk Meningkatkan Kualitas Input dan Output Siswa serta Relevansinya dengan Studi Kependidikan Islam. Jurnal Manajemen Pendidikan. Volume 24, nomor 1: halaman 32-43.

[6] Mawarsari, Venissa. 2014. Evaluasi Pembelajaran Matematika Menggunakan Model CIPP pada Kejar Paket B Kota Semarang. JKPM, Volume 1, nomor 2: halaman 42-47.
[7] Nurtanto, Muhammad. 2016. Menyiapkan Pendidikan Kejuruan Berbasis Kearifan Lokal yang Berdaya Saing. Jurnal Ilmiah Pendidikan Teknik Elektro. Volume 1, nomor 1: halaman 59-66.

[8] Rosivia. 2015. Peningkatan Pengelolaan Sarana Prasarana Pendidikan di SMP Negeri 10 Padang. Jurnal Administrasi Pendidikan UNP. Volume 2, nomor 1: halaman 636-831.

[9] Sanjaya, W. 2011. Kurikulum dan Pembelajaran, Teori dan Praktik Pengembangan Kurikulum Tingkat Satuan Pendidikan (KTSP). Jakarta: Kencana Prenada Media Group.

[10] Setyohandani, Ratna. 2013. Strategi Evaluasi Pembelajaran Program Produktif SMK. Makalah disampaikan pada Seminar Nasional Evaluasi pendidikan di Semarang pada tanggal 20 September 2013.

[11] Suwandi. 2016. Analisis Studi Kebijakan Pengelolaan Guru SMK dalam Rangka Peningkatan Mutu Pendidikan. Jurnal Pendidikan Teknologi dan Kejuruan. Volume 23, nomor 1: halaman 90-100.

[12] Tanggela, Martinus. 2013. Analisis Implementasi Kebijakan Pengelolaan Sarana dan Prasarana Sekolah di SMP Negeri 2 Batu. Jurnal Kebijakan dan Pengembangan Pendidikan Volume 1, nomor 1: halaman 26-34.

[13] Tukiman. 2009. Situasi Bengkel dan Kondisi Peralatan Praktik Pemesinan SMK Swasta di Wilayah Gerbangkertosusila. Tesis tidak diterbitkan. Malang: PPs UM.

[14] Winarto, S. 2011. Studi Tentang Kompetensi Profesional Guru Mata Diklat Produktif Teknik Komputer dan Jaringan SMK Bertaraf Internasional di Malang. Tesis tidak diterbitkan. Malang: PPs UM.

[15] Wuryandini, E. 2014. Analisis Permasalahan dan Kebutuhan Pengembangan Keprofesian Berkelanjut an Guru Smk Bidang Keahlian Bisnis dan Manajemen Pascasertifikasi di Kota Semarang. Jurnal Manajemen Pendidikan. Volume 9, nomor 2: halaman 108-119.

[16] Zulfikar, 2007. Kontribusi Pengalaman Diklat dan Kelengkapan Sarana Prasarana Praktik di SMK Terhadap Kinerja Guru Bidang Keahlian Teknik Elektro SMK di Propinsi Riau. Tesis tidak dipublikasikan. Malang: program Pascasarjana Universitas Negeri Malang. 